\title{
TREN PREVALENSI BERAT BADAN RENDAH, BERAT BADAN BERLEBIH, DAN OBESITAS PADA KELOMPOK DEWASA MUDA DI INDONESIA: 1993 - 2014
}

\author{
Defi Amalia Setia Ningrum ${ }^{\star 凶}$, Krisnawati Bantas*
}

\begin{abstract}
Abstrak
Perburukan status gizi masih menjadi determinan masalah kesehatan utama dunia, terutama pada negara berkembang. Perburukan status gizi pada usia muda merupakan prediktor yang kuat terhadap perburukan kesehatan pada usia tua. Studi ini bertujuan untuk melihat kecenderungan tren prevalensi dari berat badan rendah, berat badan lebih, dan obesitas pada masyarakat dewasa muda Indonesia pada tahun 1993-2014. Desain penelitian adalah cross-sectional series menggunakan data Indonesia Life Family Survey (ILFS) I (1993)-V (2014). Tren prevalensi dianalisis menggunakan uji chi squre untuk mengetahui besar masing-masing prevalens rasio setiap tahunnya dibandingkan dengan studi pertama pengukuran, 1993. Hasil studi menunjukan bahwa prevalensi berat badan berlebih dan obesitas tertinggi berada pada tahun $2014,27,6 \%$ dan $11,4 \%$. Tren prevalensi berat badan kurang cenderung stabil pada laki-laki dan menurun pada perempuan. Prevalensi berat badan berlebih dan obesitas kelompok usia dewasa muda di Indonesia baik pada laki-laki dan perempuan menunjukan tren yang meningkat. Hasil perhitungan prevalens rasio menunjukan signifikasi peningkatan baik pada berat badan berlebih dan obesitas terjadi pada tahun 2007 (PR BB berlebih = $1,76(95 \%$ Cl: 1,64-1,89); PR obesitas = 3,00 (95\% Cl: 2,46-3,69)) dan 2014 (PR BB berlebih $=2,26(95 \% \mathrm{Cl}: 1.97-2.60)$; PR obesitas $=4,73(95 \% \mathrm{Cl}: 3,87-5,78)$ ). Pada kelompok usia dewasa muda di Indonesia, prevalensi berat badan rendah mengalami penurunan sedangkan prevalensi berat badan berlebih dan obesitas menunjukan tren peningkatan yang siginifikan dalam satu dekade terakhir. Diperlukan manajemen dan strategi nasional gaya hidup sehat yang komprehensif untuk mengendalikan dan mencegah perburukan kesehatan di masa tua pada kelompok usia dewasa muda.
\end{abstract}

Kata kunci: berat badan berlebih, berat badan rendah, dewasa muda, obesitas, prevalensi.

\section{THE PREVALENCE OF UNDERWEIGHT, OVERWEIGHT, AND OBESITY IN INDONESIAN YOUNG ADULT, TREND BETWEEN: 1993 - 2014}

\begin{abstract}
Worsening nutritional status is the major determinant health problems worldwide, especially in developing countries. Worsening nutritional status at a young age is a strong predictor of the deterioration of health in the elderly. This study aims to estimate the prevalence and assess trends of underweight, overweight, and obesity between 1993-2014 among Indonesian Young Adult. A secondary data from Indonesia Family Life Survey (IFLS) period I (1993) to V (2014). We evaluated trends by using chi-square test to analyze the prevalence ratios (PR) of underweight, overweight, and obesity in each period compared with the first IFLS study in 1993. The results of this study showed that the highest prevalence of overweight and obesity was in $2014,27.6 \%$ and $11.4 \%$. The trend of prevalence of underweight likely to be stable in men and decreases in women. The prevalence of overweight and obesity Indonesian young adult both men and women show an increasing tendency. Results of the calculation of the prevalence ratio showed increasing significantly in both overweight and obesity in 2007 (PR overweight $=1.76$ (95\% Cl: 1.64-1.89); PR obesity = 3.00 (95\% Cl: 2.46-3.69)) and 2014 (PR overweight = 2.26 (95\% Cl: $1.97-2.60)$; obesity PR = 4.73 (95\% Cl: 3.87-5.78)). In Indonesian young adult, the prevalence of underweight decreased, otherwise the prevalence of overweight and obesity increased significantly over a decade. Management of underweight, overweight, and obesity in the young adult is required to prevent obesity and worsening health in adulthood.
\end{abstract}

Keywords: obesity, overweight, prevalence, underweight, young adult.

*Departemen Epidemiologi, Fakultas Kesehatan Masyarakat, Universitas Indonesia

E-mail: defi.amalia@ui.ac.id 


\section{Pendahuluan}

Indikator status gizi dapat dibedakan menjadi berat badan rendah, berat badan normal, berat badan berlebih, dan obesitas. Di dunia, sebanyak 1.9 milyar orang dewasa mengalami obesitas dan 462 juta orang dewasa mengalami berat badan rendah. ${ }^{1}$ Negara berkembang merupakan kelompok negara dengan angka prevalensi berat badan rendah tertinggi di dunia, yaitu mencapai $16,8 \%$ (IMT), dan prevalensi berat badan berlebih/obesitas mencapai $27 \%{ }^{1} \quad \mathrm{Di}$ Indonesia, hasil RISKESDAS tahun 2013 pada masyarakat di atas 18 tahun menunjukan $8,7 \%$ mengalami berat badan rendah, 13,3\% mengalami berat badan berlebih, dan $15,4 \%$ mengalami obesitas. ${ }^{2}$

Kelompok usia dewasa muda merupakan kelompok usia transisi dari remaja menuju dewasa. ${ }^{3}$ Pada masa tersebut kelompok dewasa muda mengalami perubahan hidup yang signifikan, seperti memulai berkuliah, mulai berkerja, mengembangkan relasi, menikah, dan merawat anak. ${ }^{4,5}$ Penyesuaian terhadap interaksi sosial, psikologis, dan biologis pada lingkungan baru membuat kelompok dewasa muda rentan terhadap pola perubahan konsumsi yang mengakibatkan ketidakseimbangan energi yang dikonsumsi dalam tubuh. ${ }^{6}$

Berat badan rendah pada usia muda dapat mengakibatkan rendahnya kepadatan mineral tulang dan kekebalan tubuh menurun sehingga mudah terserang penyakit menular. Sedangkan kelebihan berat badan pada usia muda merupakan prediktor yang kuat terhadap perburukan kesehatan jangka panjang pada usia tua seperti sindrom metabolik, atherosclerosis, penyakit jantung, diabetes, kolesterol tinggi, kanker dan gangguan tidur. ${ }^{7}$

Beberapa penelitian menunjukan adanya variasi peningkatan dan penurunan prevalensi berat badan rendah, berat badan berlebih, dan obesitas berdasarkan jenis kelaminnya. Peningkatan prevalensi berat badan berlebih cenderung banyak terjadi pada pria. Namun, peningkatan prevalensi obesitas cenderung lebih banyak terjadi pada perempuan 8,9 .

Kurang dan berlebihnya berat badan mengakibatkan meningkatnya pembiayaan pelayanan kesehatan, menurunkan produktifitas dan memperlambat pertumbuhan ekonomi yang akan menyebabkan kekalnya kemiskinan dan angka kesakitan suatu negara. ${ }^{10}$ Monitoring perubahan prevalensi berat badan rendah, berat badan berlebih, dan obesitas dapat digunakan untuk menentukan kebutuhan dan prioritas nasional, dan evaluasi program pengendalian perburukan status gizi oleh pemerintah. Tujuan dari studi ini adalah untuk melihat kecenderungan tren dari prevalensi berat badan rendah, berat badan lebih, dan obesitas pada masyarakat dewasa muda Indonesia pada tahun $1993-2014$.

\section{Bahan dan Metode}

Desain studi yang digunakan dalam penelitian ini adalah cross-sectional series. Penelitian ini menggunakan data Indonesia Family Life Survey (IFLS) I-V. IFLS merupakan studi cross-sectional series yang dilaksanakan di 13 dari 27 provinsi pada tahun 1993, 1997, 2000, 2007, dan 2014 yang dipilih menggunakan stratified random sampling. Pengambilan data pada IFLS telah melalui studi kelayakan oleh United States of America (Institutional Review Board at Rand Corporation, Santa Monica, California) dan Komisi Etik Fakultas Kesehatan Masyarakat Universitas Indonesia dengan nomor surat keterangan: 22/UN2.F10/PPM.00.02/2019.

IFLS merupakan survei multiguna yang terbagi menjadi dua kategori, yaitu survei rumah tangga (household survey) yang berisikan informasi tingkat rumah tangga dan individu, serta survei komunitas dan fasilitas (community-facility survey) yang berisikan 
data fasilitas kesehatan dan pendidikan, kegiatan sosial komunitas, dan harga pangan wilayah komunitas setempat. Penelitian ini menggunakan data survei rumah tangga (household survey) IFLS I-V, dengan populasi target adalah seluruh kelompok dewasa muda pada 13 provinsi di Indonesia. Variabel bebas dalam penelitian ini adalah tahun periode IFLS, sedangkan variabel terikat dalam penelitian ini adalah indikator status gizi yang dibedakan atas berat badan kurang, berat badan berlebih, dan obesitas. Indeks Masa Tubuh (IMT) digunakan untuk menentukan indikator status gizi. IMT dihitung dengan membagi berat badan $(\mathrm{kg})$ dengan kuadrat tinggi badan $\left(\mathrm{m}^{2}\right)$. IMT $<18,5 \mathrm{~kg} / \mathrm{m}^{2}$ diklasifikasikan ke dalam berat badan rendah, IMT $\quad 18,5-24,9 \mathrm{~kg} / \mathrm{m}^{2}$ diklasifikasikan $\mathrm{ke}$ dalam berat badan normal, IMT 25-29,9 $\mathrm{kg} / \mathrm{m}^{2}$ diklasifikasikan ke dalam berat badan lebih, dan IMT $\geq 30 \mathrm{~kg} / \mathrm{m}^{2}$ masuk ke dalam klasifikasi obesitas.

Kriteria inklusi dalam penelitian ini adalah masyarakat Indonesia berumur 19-39 tahun. Individu dengan umur lebih rendah dari 18 tahun, lebih dari 40 tahun, wanita mengandung, dan individu dengan ketidaklengkapan pengukuran antropometri dikeluarkan dari studi ini. Sebanyak 5.978 responden pada IFLS I, 8.842 responden pada IFLS II, 12.521 responden pada IFLS III, 15.332 responden pada IFLS IV, dan 16.464 responden pada IFLS $V$ merupakan total sampel yang akan digunakan untuk menggambarkan tren prevalensi berat badan rendah, berat badan berlebih, dan obesitas pada kelompok dewasa muda di Indonesia berdasarkan jenis kelamin.

Analisis deskriptif digunakan untuk menyajikan karakteristik dasar studi populasi. Uji chi squre digunakan untuk mengetahui besar masing-masing prevalens rasio $(95 \%$ $\mathrm{Cl})$ dari berat badan rendah, berat badan lebih, dan obesitas pada periode IFLS II-V dibandingkan dengan berat badan rendah, berat badan lebih, dan obesitas pada periode
IFLS I. Keseluruhan data dianalisis dengan menggunakan STATA versi 14.1.

\section{Hasil}

Secara keseluruhan rata-rata tinggi badan, berat badan, dan IMT kelompok dewasa muda di Indonesia meningkat setiap tahunnya (Tabel 1). Peningkatan tertinggi tinggi badan, berat badan, dan IMT terjadi pada tahun 2007. Pada laki-laki, rata-rata tinggi badan dan berat badan menunjukan tren peningkatan dari tahun 1993-2014. Rata-rata IMT pada laki-laki stabil pada tahun 1993-2000 kemudian meningkat dan membentuk puncak pada tahun 2007, lalu menurun pada akhir pengamatan yaitu tahun 2014. Berbeda dengan laki-laki, tren rata-rata tinggi badan pada perempuan menunjukan angka yang fluktuatif. Rata-rata berat badan dan indeks masa tubuh pada perempuan menunjukan tren yang sama dengan laki-laki. Rata-rata IMT tertinggi baik pada laki-laki dan perempuan terjadi pada tahun 2007 (IFLS IV) masing-masing $25,43 \mathrm{~kg} / \mathrm{m}^{2}$ dan $26,27 \mathrm{~kg} / \mathrm{m}^{2}$. Peningkatan IMT secara siginifikan dapat terjadi karena peningkatan rata-rata berat badan lebih besar daripada peningkatan ratarata tinggi badan.

Tren dan Prevelensi Berat Badan Rendah, Berat Badan Berlebih, dan Obesitas Tahun 1993 - 2014

Tren prevalensi berat badan rendah kelompok dewasa muda di Indonesia (Gambar 1) secara keseluruhan dan pada kelompok perempuan menunjukan tren peningkatan pada tahun 1993-2000, kemudian menurun pada tahun 2007, dan mencapai titik terendah pada tahun 2014. Namun, pada kelompok laki-laki prevalensi berat badan rendah stabil pada dua periode akhir pengamatan. Bila dibandingkan dengan prevalensi pada tahun 1993, prevalensi berat badan rendah pada laki-laki di tahun 2014 menunjukan peningkatan. 
Pada tren prevalensi berat badan berlebih (Gambar 2) dapat dilihat bahwa prevalensi perempuan dengan berat badan berlebih lebih tinggi daripada laki-laki. Tren prevalensi berat badan berlebih baik secara keseluruhan, pada laki-laki maupun perempuan menunjukan tren yang sama, yaitu menurun pada tahun 1997 kemudian meningkat secara berangsur-angsur hingga tahun 2014.

Sama seperti prevalensi berat badan berlebih, prevalensi perempuan dengan obesitas lebih tinggi daripada prevalensi obesitas pada laki-laki (Gambar 3). Berbeda dengan tren prevalensi berat badan rendah dan berat badan tinggi yang menunjukan adanya peningkatan dan penurunan selama periode pengamatan, tren prevalensi obesitas selalu meningkat dari awal hingga akhir periode pengamatan. Peningkatan prevalensi obesitas secara signifikan terjadi pada tahun 2007, dan mencapai puncak pada tahun 2014.

Prevalensi Rasio Berat Badan Rendah, Berat Badan Berlebih, dan Obesitas Tahun 1993 - 2014

Pada Tabel 2 menyajikan prevalens rasio $(95 \% \mathrm{Cl})$ berat badan rendah, berat badan lebih, dan obesitas pada setiap periode pengamatan. Secara keseluruhan, prevalens rasio berat badan rendah dari tahun ke tahun menunjukan penurunan, sedangkan prevalens rasio berat badan berlebih dan obesitas dari tahun ke tahun menunjukan peningkatan.

Tren prevalens rasio berat badan rendah dari tahun ke tahun secara keseluruhan, pada kelompok laki-laki, maupun pada kelompok perempuan tidak menunjukan perubahan bermakna disebabkan oleh nilai rentang confidence interval $(\mathrm{Cl})$ saling mengiris satu sama lain. Tren prevalens ratio pada berat badan berlebih dan obesitas pada ketiga kelompok pengamatan (keseluruhan, laki-laki, perempuan) menunjukan tidak banyak perubahan antara tahun 1997 hingga 2000. Perubahan pravelens ratio berat badan berlebih dan obesitas pada ketiga kelompok pengamatan menunjukan adanya peningkatan secara bermakna pada tahun 2007 dan 2014. Angka prevalens rasio tertinggi pada berat badan berlebih dan obesitas baik pada laki-laki dan perempuan terjadi pada tahun 2014 dengan angka prevalens rasio untuk berat badan berlebih pada laki-laki dan perempuan masingmasing, 2,26 (95\% Cl: 1,97-2,60) dan 1,56 (95\% Cl: 1,43-1,70), dan angka prevalens rasio obesitas tertinggi pada laki-laki dan perempuan masing-masing, 9,93 (95\% Cl: 5,45-18,12) dan 4,09 (95\% Cl: 3,30-5,06). 
Tabel 1. Karakteristik dasar studi populasi kelompok dewasa muda umur 19-39 tahun di Indonesia.

\begin{tabular}{|c|c|c|c|c|c|}
\hline & IFLS I-1993 & IFLS II-1997 & IFLS III- 2000 & IFLS IV-2007 & IFLS V-2014 \\
\hline \multicolumn{6}{|l|}{ Keseluruhan } \\
\hline Jumlah sampel & $N=5,978$ & $N=8,842$ & $N=12,521$ & $N=15,332$ & $N=16,464$ \\
\hline Tinggi (cm) & $\begin{array}{l}154,69 \\
(154,48-154,89)\end{array}$ & $\begin{array}{l}155,62 \\
(155,45-155,79)\end{array}$ & $\begin{array}{l}156,63 \\
(156,38-156,67)\end{array}$ & $\begin{array}{l}156,32 \\
(156,13-156,51)\end{array}$ & $\begin{array}{l}157,55 \\
(157,42-157.54)\end{array}$ \\
\hline Berat $(\mathrm{kg})$ & $\begin{array}{l}51,96 \\
(51,74-52,18)\end{array}$ & $\begin{array}{l}52,39 \\
(52,20-52,58)\end{array}$ & $\begin{array}{l}53,08 \\
(52,91-53,25)\end{array}$ & $\begin{array}{l}55,17 \\
(55,00-55,34)\end{array}$ & $\begin{array}{l}57,78 \\
(57,60-57,96)\end{array}$ \\
\hline $\begin{array}{l}\text { Indeks Massa } \\
\text { Tubuh (kg/m²) }\end{array}$ & $\begin{array}{l}21,70 \\
(21,61-21,80)\end{array}$ & $\begin{array}{l}21,61 \\
(21,54-21,78)\end{array}$ & $\begin{array}{l}21,67 \\
(21,60-21,74)\end{array}$ & $\begin{array}{l}25,87 \\
(24,61-27,14)\end{array}$ & $\begin{array}{l}23,28 \\
(23,21-23,35)\end{array}$ \\
\hline \multicolumn{6}{|l|}{ Laki-laki } \\
\hline Jumlah sampel & $N=2,418$ & $N=3,851$ & $N=5,865$ & $N=7,240$ & $N=7,548$ \\
\hline Tinggi $(\mathrm{cm})$ & $\begin{array}{l}161,33 \\
(161,08-161,59)\end{array}$ & $\begin{array}{l}162,11 \\
(161,92-162,30)\end{array}$ & $\begin{array}{l}162,78 \\
(162,62-162,94)\end{array}$ & $\begin{array}{l}162,30 \\
(162,03-162,57)\end{array}$ & $\begin{array}{l}164,06 \\
(163,93-164,20)\end{array}$ \\
\hline Berat $(\mathrm{kg})$ & $\begin{array}{l}55,29 \\
(54,96-55,61)\end{array}$ & $\begin{array}{l}55,39 \\
(55,11-55,65)\end{array}$ & $\begin{array}{l}55,94 \\
(55,69-56,17)\end{array}$ & $\begin{array}{l}57,79 \\
(57,55-58,03)\end{array}$ & $\begin{array}{l}59,97 \\
(59,71-60,23)\end{array}$ \\
\hline $\begin{array}{l}\text { Indeks Massa } \\
\text { Tubuh }\left(\mathrm{kg} / \mathrm{m}^{2}\right)\end{array}$ & $\begin{array}{l}21,20 \\
(21,09-21,30)\end{array}$ & $\begin{array}{l}21,04 \\
(20,96-21,13)\end{array}$ & $\begin{array}{l}21,07 \\
(20,10-21,15)\end{array}$ & $\begin{array}{l}25,43 \\
(23,60-27,26)\end{array}$ & $\begin{array}{l}22,24 \\
(22,15-22,32)\end{array}$ \\
\hline \multicolumn{6}{|l|}{ Perempuan } \\
\hline Jumlah sampel & $N=3,560$ & $\mathrm{~N}=4,991$ & $N=6,658$ & $N=8,092$ & $N=8,916$ \\
\hline Tinggi (cm) & $\begin{array}{l}14980 \\
(149,99-150,36)\end{array}$ & $\begin{array}{l}150,62 \\
(150,47-150,78)\end{array}$ & $\begin{array}{l}151,02 \\
(150,88-150,16)\end{array}$ & $\begin{array}{l}150,98 \\
(150,77-151,18)\end{array}$ & $\begin{array}{l}152,04 \\
(151,93-152,15)\end{array}$ \\
\hline Berat $(\mathrm{kg})$ & $\begin{array}{l}49,56 \\
(49,42-49,98)\end{array}$ & $\begin{array}{l}50,08 \\
(49,84-50,32)\end{array}$ & $\begin{array}{l}50,57 \\
(50,35-50,79)\end{array}$ & $\begin{array}{l}52,82 \\
(52,59-53,05)\end{array}$ & $\begin{array}{l}55,92 \\
(55,68-56,15)\end{array}$ \\
\hline $\begin{array}{l}\text { Indeks Massa } \\
\text { Tubuh }\left(\mathrm{kg} / \mathrm{m}^{2}\right)\end{array}$ & $\begin{array}{l}22,04 \\
(21,91-22,19)\end{array}$ & $\begin{array}{l}22,05 \\
(21,95-22,15)\end{array}$ & $\begin{array}{l}22,19 \\
(22,08-22,31)\end{array}$ & $\begin{array}{l}26,27 \\
(24,51-28,03)\end{array}$ & $\begin{array}{l}24,16 \\
(24,07-24,26)\end{array}$ \\
\hline
\end{tabular}




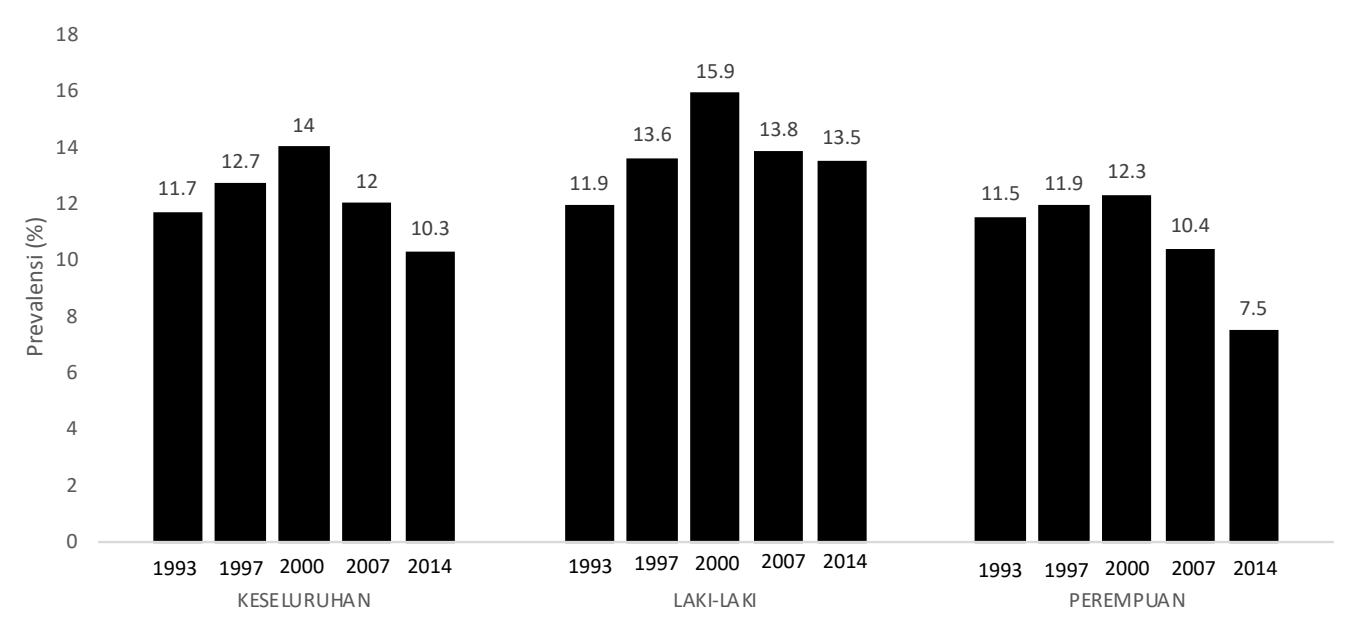

Gambar 1. Tren prevalensi berat badan rendah $\left(<18,5 \mathrm{~kg} / \mathrm{m}^{2}\right)$ pada kelompok dewasa muda di Indonesia tahun $1993-2014$.

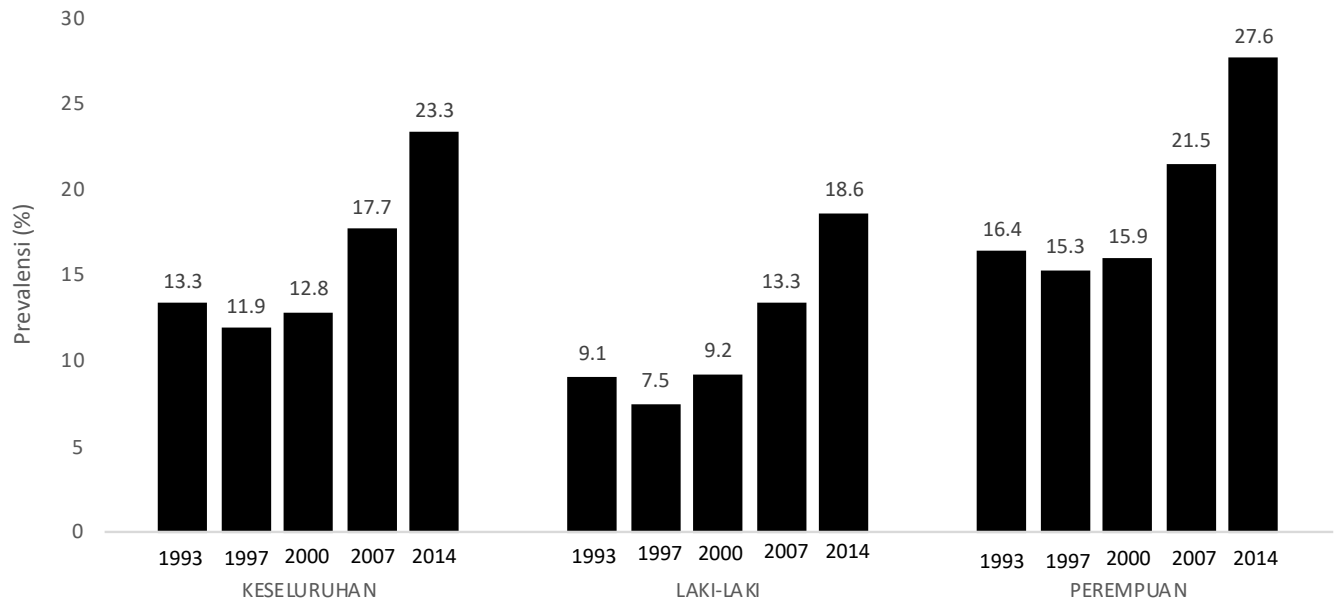

Gambar 2. Tren prevalensi berat badan berlebih $\left(25-29,9 \mathrm{~kg} / \mathrm{m}^{2}\right)$ pada kelompok dewasa muda di Indonesia tahun 1993 - 2014.

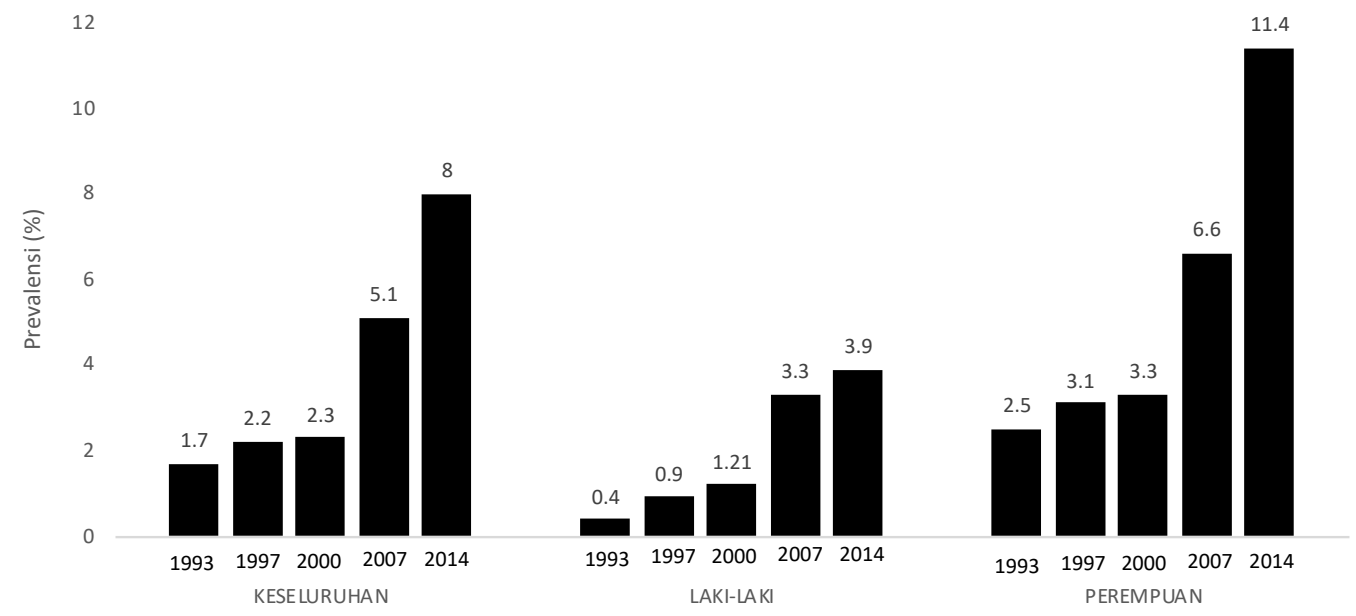

Gambar 3. Tren prevalensi obesitas $\left(\geq 30 \mathrm{~kg} / \mathrm{m}^{2}\right)$ pada kelompok dewasa muda di Indonesia Tahun $1993-2014$. 
Tabel 2. Prevalens rasio berat badan rendah, berat badan berlebih, dan obesitas $1993-2014$ pada kelompok dewasa muda di Indonesia berdasarkan jenis kelaminnya.

\begin{tabular}{|c|c|c|c|}
\hline & Berat Badan Rendah PR (95\% Cl) & Berat Badan Berlebih PR (95\% Cl) & Obesitas PR $(95 \% \mathrm{Cl})$ \\
\hline \multicolumn{4}{|c|}{ Keseluruhan } \\
\hline $\mathrm{I}(1993)$ & 1 (ref) & 1 (ref) & 1 (ref) \\
\hline II (1997) & $1,09(0,99-1,19)$ & $0,90(0,83-0,98)$ & $1,27(1,00-1,61)$ \\
\hline III (2000) & $1,20(1,10-1,30)$ & $0,97(0,89-1,05)$ & $1,38(1,10-1,73)$ \\
\hline IV (2007) & $1,03(0,95-1,12)$ & $1,33(1,24-1,44)$ & $3,00(2,46-3,69)$ \\
\hline V (2014) & $0,09(0,81-0,95)$ & $1,76(1,64-1,89)$ & $4,73(3,87-5,78)$ \\
\hline \multicolumn{4}{|l|}{ Laki-laki } \\
\hline $\mathrm{I}(1993)$ & 1 (ref) & 1 (ref) & 1 (ref) \\
\hline II (1997) & $1,23(1,07-1,42)$ & $0,89(0,75-1,06)$ & $2,21(1,13-4,34)$ \\
\hline III (2000) & $1,55(1,36-1,76)$ & $1,17(1,01-1,37)$ & $3,08(1,63-5,81)$ \\
\hline IV (2007) & $1,35(1,19-1,54)$ & $1,71(1,48-1,97)$ & $8,47(4,63-15,49)$ \\
\hline V (2014) & $1,28(1,13-1,45)$ & $2,26(1,97-2,60)$ & $9,93(5,45-18,12)$ \\
\hline \multicolumn{4}{|c|}{ Perempuan } \\
\hline I (1993) & 1 (ref) & 1 (ref) & 1 (ref) \\
\hline II (1997) & $0,98(0,87-1,11)$ & $0,90(0,81-1,00)$ & $1,16(0,89-1,50)$ \\
\hline III (2000) & $0,95(0,85-1,07)$ & $0,89(0,81-0,98)$ & $1,17(0,92-1,50)$ \\
\hline IV (2007) & $0,80(0,72-0,90)$ & $1,19(1,09-1,30)$ & $2,33(1,87-2,91)$ \\
\hline V (2014) & $0,60(0,53-0,67)$ & $1,56(1,43-1,70)$ & $4,09(3,30-5,06)$ \\
\hline
\end{tabular}

\section{Pembahasan}

Berdasarkan hasil analisis yang telah dilakukan, perempuan memiliki angka prevalensi yang lebih tinggi daripada laki-laki baik pada variabel berat badan berlebih dan obesitas. Tren prevalensi berat badan rendah cenderung stabil pada laki-laki dan menurun pada perempuan. Namun, prevalensi berat badan berlebih dan obesitas kelompok usia dewasa muda di Indonesia, baik pada laki-laki dan perempuan menunjukan tren yang meningkat, dengan angka prevalensi berat badan berlebih lebih tinggi dibandingkan dengan prevalensi obesitas.

Tren berat badan rendah yang stabil pada laki-laki dan penurunan pada perempuan kelompok usia dewasa muda di Indonesia berkebalikan dengan studi prevalensi berat badan rendah pada kelompok usia dewasa muda di Korea (19982012) dan Amerika (1999-2008). Kedua studi tersebut menunjukan adanya peningkatan tren prevalensi berat badan rendah baik pada laki-laki maupun perempuan, meskipun peningkatan prevalensi berat badan kurang tidak sebesar peningkatan prevalensi berat badan berlebih dan obesitas. ${ }^{3,8}$

Tingginya prevalensi berat badan berlebih daripada obesitas pada kelompok usia dewasa muda di Indonesia sesuai dengan hasil studi sistematik review pada 22 negara berkembang yang menyatakan bahwa prevalensi berat badan berlebih lebih tinggi $16,8-25,9 \%$ dari prevalensi obesitas pada kelompok usia dewasa muda. ${ }^{6}$ Studi oleh Gregory tahun 2006 menyatakan bahwa ratarata berat badan kelompok dewasa muda di negara berkembang akan meningkat 1 $\mathrm{kg} / \mathrm{tahun}$, lebih tinggi daripada rata-rata berat badan kelompok usia dewasa muda di negara maju (0,4-0,9 kg/tahun).3,11

Adanya peningkatan ekonomi serta kemandirian finansial pada kelompok dewasa muda di negara berkembang mengakibatkan semakin banyak dan mempermudah akses dalam mengkonsumsi makanan siap saji. ${ }^{12}$ Faktor risiko lainnya yang menunjang 
terjadinya berat badan berlebih dan obesitas pada kelompok usia dewasa muda adalah perubahan gaya hidup aktif ke gaya hidup sedentari. Padatnya waktu karena komitmen kerja, adanya sistem rotasi jam kerja, serta kurangnya waktu tidur untuk berkerja mengakibatkan kelompok usia ini terbatas untuk melakukan aktifitas fisik. ${ }^{13}$

Pada studi ini, meskipun perempuan memiliki prevalensi berat badan berlebih dan obesitas lebih tinggi daripada laki-laki, namun hasil analisis besar asosiasi menunjukan bahwa prevalens rasio perempuan untuk mengalami berat badan berlebih dan obesitas lebih rendah daripada laki-laki. Laki-laki memiliki risiko peningkatan prevalensi obesitas 9,93 kali lebih besar pada tahun 2014 daripada tahun 1993. Sementara itu, pada perempuan, risiko peningkatan prevalensi obesitas 4,09 kali lebih besar pada tahun 2014 daripada tahun 1993. Lebih tingginya risiko peningkatan prevalensi obesitas pada laki-laki dapat terjadi karena laki-laki cenderung acuh terhadap persepsi bentuk tubuhnya, sedangkan pada perempuan persepsi citra tubuh yang kurus dan langsing mengakibatkan perempuan lebih mudah mengontrol perilaku konsumsi mereka. ${ }^{9}$ Selain itu, tingginya prevalens rasio pada laki-laki dapat diakibatkan oleh kebiasaan hidup merokok. Prevalensi perokok di Indonesia terus meningkat dari 27\% (1995), 31,5\% (2001), dan menjadi 34,4\% (2004). ${ }^{14}$ Data laporan WHO dalam The Global Tobacco Epidemic (2017) menyebutkan bahwa $75 \%$ laki-laki dewasa di Indonesia memiliki kebiasaan merokok. ${ }^{15}$ Beberapa penelitian yang menunjang hal tersebut menunjukan bahwa merokok dapat meningkatkan risiko terjadinya obesitas. ${ }^{16,17}$

Beberapa kelemahan dari studi ini adalah analisis tren prevalensi hanya disajikan berdasarkan jenis kelamin saja. Risiko bias seleksi dapat terjadi akibat seleksi ketidaklengkapan data pengukuran antropometri. Namun, studi ini memiliki kelebihan berupa jumlah sampel yang besar, sehingga lebih dapat merepresentasikan kondisi populasi umum dan pada penelitian ini, dan tren pravelensi pada penelitian ini disajikan dalam kurun waktu lebih dari satu dekade.

\section{Kesimpulan}

Prevalensi berat badan rendah pada kelompok dewasa muda pada kelompok usia dewasa muda di Indonesia tahun tidak banyak mengalami perubahan. Prevalensi berat badan berlebih dan obesitas pada kelompok usia dewasa muda di Indonesia menunjukkan tren peningkatan yang siginifikan dalam satu dekade terakhir.

\section{Saran}

Manajemen dan strategi nasional yang komprehensif, seperti adanya kegiatan aktifitas fisik rutin, deteksi dini dan promosi gaya hidup sehat di lingkungan kerja diperlukan untuk mencegah perburukan kesehatan di masa tua. Penelitian lebih lanjut terkait tren perubahan pola konsumsi diperlukan untuk mengetahui korelasinya dengan peningkatan prevalensi berat badan berlebih dan obesitas pada kelompok usia dewasa muda di Indonesia.

\section{Daftar Pustaka}

1. WHO. Malnutrition: Key facts [Internet]. World Health Organization. 2016 [cited 2018 Oct 7]. Available from: http://www.who.int/news-room/factsheets/detail/malnutrition

2. Kementerian Kesehatan RI. Riset Kesehatan Dasar. 2013.

3. Anderson DA, JR S, JD L. The Freshman Year of College as A Critical Period of Weight Gain: An Initial Evaluation. Eat Behav. 2003; 3:367. 
4. Burke V, Beilin LJ, Dunbar D KM. Changes in Health-Related Behaviours and Cardiovascular Risk Factors in Young Adults: Associations with Living with A Partner. Prev Med. 2004; 39:722.

5. Butler SM, Black DR, Blue $\mathrm{CL}$ GR. Change in Diet, Physical Activity, and Body Weight in Female College Freshman. Am J Heal Behav. 2004; 28:24-32.

6. Aucott L, Poobalan A, McCallum M SW. Mental Wellbeing Related to Lifestyle and Risky Behaviours in 18-25 Year Old: Evidence from North East Scotland. Int J Pub Heal Res. 2014; 4:431.

7. Santos MG, Pegoraro M, Sandrini F ME. Risk factors for the development of atherosclerosis in childhood and adolescence. Arq Bras Cardiol. 2008;90:276.

8. Lim J, Hye Soon P. Trends in the Prevalence of Underweight, Obesity, Abdominal Obesity and Their Related Lifestyle Factors in Korean Young Adults, 1998-2012. Obes Res Clin Pract. 2016; 9.

9. Poobalan A, Aucott L. Obesity Among Young Adults in Developing Countries: A Systematic Overview. Curr Obes Rep [Internet]. 2016;5(1):2-13. Available from: http://link.springer.com/10.1007/s13679016-0187-x

10.Van de Poel E, Hosseinpoor AR, Speybroeck N, Van Ourti T, Vega J. Socioeconomic Inequality in Malnutrition in Developing Countries. Bull World Health Organ [Internet]. 2008 [cited 2018
Oct 7]; 86:282-91. Available from: https://www.scielosp.org/scielo.php?pid=S 004296862008000400013\&script=sci_artt ext\&tlng=es

11.Gregory C, Martorell R, Narayan K, Ramirez-Zea M, Stein A. Five-Year Changes in Adiposity and CardioMetabolic Risk Factors Among Guatemalan Young Adults. Public Heal Nutr. 2009; 228.

12.Berkey CS, Rockett HR, Field AE, Gillman MW, GA Colditz. Sugar-Added Beverages and Adolescent Weight Change. Obes Res. 2004; 778.

13. Marmot M. Multilevel Approaches To Understanding Social Determinants. In: Berkma. Oxford: Oxford University Press; 2000. p. 349.

14.Tobacco Control Support Center. Fakta Tembakau di Indonesia. Riz'ma. Jakarta: IAKMI; 2009. HIm. 15-87.

15.WHO. WHO Report on the Global Tobacco Epidemic, 2017. Country Profile: United Kingdom of Great Britain and Northern Ireland [Internet]. 2017. Available from:http://www.who.int/tobacco/surveillan ce/policy/country_profile/gbr.pdf

16.Carreras-Torres R, Johansson M, Haycock PC, Relton CL, Davey Smith G, Brennan $P$, et al. Role of Obesity in Smoking Behaviour: Mendelian Randomisation Study in UK Biobank. BMJ. 2018; 361.

17.Dare S, Mackay DF, Pell JP. Relationship between Smoking and Obesity: A CrossSectional Study of 499,504 Middle-Aged Adults in the UK General Population. PLoS One. 2015;10(4):1-12. 